\title{
PHYSICO-CHEMICAL, SENSORY AND COLOUR ANALYSIS OF PEDA PREPARED USING CaesalpiniaSappanL. AS NATURAL COLOURANT.
}

\author{
Rishi Kumar Puri ${ }^{*}$, P. I. Geevarghese ${ }^{2}$. \\ 1Scholar, Kerala Veterinary and Animal Sciences University. \\ 2 Department of Dairy Chemistry, College of Dairy Science and Technology, KVASU. \\ *rishi233@gmail.com
}

\begin{abstract}
:
The study was conducted to standardize the preparation of peda using Caesalpiniasappan Linn. heartwood extract as natural colourant. The level of addition of the extract and the point at which it is to be added in the preparation process was standardized by comparing statistical analysis of sensory scores. According to the results obtained, 0.09 per-cent of extract added during preparation at a concentration of 65 per-cent total solids gave highest sensory scores as compared to other treatments.
\end{abstract}

Key words: Peda, CaesalpiniasappanLinn., natural colour, colour analysis, physoco-chemical analysis.

\section{INTRODUCTION}

India ranks first in the world in milk production with about 132.8 million tons of milk per year. Owing to the centuries old civilization and culture, milk and milk products are deeply integrated with the society and are part and parcel of almost all kinds of occasions. Out of the total milk produced, almost 50 to 55 percent of total milk produced in the country is converted into various traditional products.

Several traditional techniques are used at households and farms to preserve surplus milk. This has led to the production of several indigenous milk products. One such indigenous milk product is khoa where in large portion of water in milk is removed to obtain milk solids with very low water activity. Khoa is further used as base material for variety of highly nutritious and palatable sweets which are comparatively shelf stable. Among the traditional milk products khoa occupies a premium position due to its wide acceptability, high nutritive value and demand. About 7 per-cent of total milk produced in India is converted to khoa and sweets made out of it.

Peda and burfi are the main products prepared using khoa as the base material. 'Peda' is a very popular delicacy liked not only in India but all over the Indian subcontinent. The colourof pedaranges from creamy white to yellow and dark reddish brown. There are a number of peda variants available throughout the country, developed over a period of time. Most popular variants are Mathura Peda and DharwadPeda, also known as lalPeda or red peda. Traditionally saffron is used for colouring 'Peda' and the colour varies depending on the concentration of saffron. Due to high cost and less availability, the use of saffron on an industrial scale for colouring is limited. As an alternative to obtain brown colour, khoa is heated with sugar on a gentle fire which induces mailard reaction resulting in brown colour. Prolonged treatment during this process results in denaturation of milk constituents and yields a higher free fat.

The consumer acceptance of a food product is largely based on the colour, flavour, body and texture. The popularity of Mathura peda proves that most popular and desirable colour for peda is reddish brown. As per the standards synthetic colour is not permitted in khoa or peda. Another alternative is to add natural colouring agents which are safe, heat stable with functional attributes. Looking at the food colour industry, a safe red colour is in demand keenly by the consumers as well as producers as a replacement for the most widely used synthetic colour 'allura red' or 'red 40'.

Caesalpiniasappanalso known as Brazilwood or 'Pathimukham' is a small thorny tree, 6-9 metre in height found in India, Peru, Malayasia etc. The heartwood of Caesalpiniasappan is orange-red, hard and very heavy. It contains water soluble dyes such as brazilin, 
protosappanins and haematoxylin (Senthilkumaret al., 2011). The extract of this heartwood is reported to have great therapeutic value as, antiinflammatory, antiproliferative, antiviral, antimicrobial, vasorelaxing, anticonvulsant, anticoagulant,immunostimulant, withantioxidant properties(Srilakshmiet al., 2010).

Red dye from CaesalpiniasappanLinn.heartwoodis found to be a promising alternative as a food colourant as it is safe and rather healthy with a wide range of functional properties. It's traditional and established use in medicine and food itemsin China and all over the southern Asia makes it easily acceptable.The literature available on the use of Caesalpiniasappan in food is scanty.However, its use as antioxidant and antimicrobial agent in food items is available.

\section{EXPERIMENTAL}

The work was carried out in the department of dairy technology, College of Dairy Science and Technology, Kerala Veterinary and Animal Sciences University, Kerala, India. Milk (Standardized buffalo milk; $6 \%$ fat and $9 \%$ SNF) used for manufacturing of peda was procured from University Dairy Plant, College of Veterinary and Animal Sciences, Kerala Veterinary and Animal Sciences University, Kerala, India. Iron 'karahi' (vessel) and steel ladle were purchased locally from Thrissur market for peda preparation. The Caesalpiniasappan heartwood was procured from the Kerala Agricultural University. Packaging material such as parchment paper was bought from local market and LLDPE pouches of size $10 \mathrm{~cm} \times 5$ $\mathrm{cm}$ were purchased from Capricorn Polymers Packaging, Arimbur, Kerala.

\section{Colour extraction from Caesalpiniasappan heartwood}

The heartwood was made to small chips and dried in sun to prevent spoilage. A modified version of combined aqueous and ethanolic extraction procedure (as described by Lioe, et al., 2012) was followed. $200 \mathrm{~g}$ of chipped Caesalpiniasappan heartwood was boiled in 2 liter mixture of water and ethanol in the ratio of $1: 1(\mathrm{v} / \mathrm{v})$. The solution was brought to one-fourth of initial quantity and then screened to get concentrated liquid extract. This extract was subjected to lyophillization to get dried powder extract.

\section{Peda preparation}

The 'Peda' was prepared according to standard procedure as described by Anejaet al. (2002). Standardized milk was taken in an open iron vessel (karahi) which was heated with gentle and continuous stirring using steel ladle.After reaching 2.5 to 3 times concentration, flame was reduced andstirred vigorously to collect the solids into a semi-solid pat. The vessel was removed from fire and the contents wereworked for 5-10 minutes to bring all the solids into a single khoa pat and to get desired body and texture. Obtained khoa was mixed with powdered sugar ( 35 percent w/w of khoa) and was mixed thoroughly over a gentle fire to obtain a relatively firm mass. This was molded into flat round shaped pieces which were wrapped in parchment paper and packaged with LLDPE pouches.Samples were stored in a dark dry place.

\section{Colour addition}

Standardization of concentration of colour extract to be added was done in two steps viz. preliminary standardization and optimization. In preliminary standardization, the level of colour extract addition was standardized on the basis of sensory scores and colour characteristics. Three different levels of colour extract concentrations were analysed viz. 0.09 per cent (T1), 0.1 per cent (T2) and 0.11 per cent (T3). In optimization step, the point of addition of colour extract in peda preparation was standardized according to the sensory scores, colourcharacteristics and anti-oxidant activity in each treatment. Two treatments were carried out for optimization. In first treatment the colour extract was added to the milk just before commencement of the khoa preparation (P1). In second treatment the colour extract was added during product preparation at 65 per cent total solids (P2). Results from preliminary and optimization trials were subjected to statistical analysis to obtain results.

\section{Measurement of antioxidant value}

$2.6 \mathrm{mg}$ 2,2-diphenyl-1-picrylhydrazyl (DPPH) was dissolved in $100 \mathrm{ml}$ methanol to prepare a standard solution. $50 \mathrm{mg}$ of sample was mixed with $50 \mathrm{ml}$ methanol and vortex until it was dissolved completely. To $1 \mathrm{ml}$ of this sample solution, $0.5 \mathrm{ml}$ methanol and $1.5 \mathrm{ml} \mathrm{DPPH}$ standard solution was added. This was incubated at 37 ${ }^{\circ} \mathrm{C}$ for 30 minutes. Absorbance was read at $516 \mathrm{~nm}$. 


\section{Physico-chemical analysis}

$\mathrm{pH}$ of peda sample was determined as per the procedure followed by O' Keeffeeet al. (1976). Titratable aciditywas measured according to method described by AOAC (1997) for cheese. Fat percentwas measured by method described in BIS handbook (SP: 18, 1981) Protein: The total nitrogen content of the peda was determined by Micro Kjeldahl method (AOAC, 1997). Moisture and total solidsin peda samples was determined by the method of Sachdeva (1983).Ash content of peda was determined using the method described for chhana in BIS handbook (SP: 18, 1981).

\section{Changes in sensory attributes}

The sensory attributes ofpedawere analyzed for colour, flavour, texture, sweetnessand overall acceptability by a panel of 6 expert judgesby using anine point hedonic scale (1 dislike extremely; 9 like extremely). Eighteen replications were taken in preliminary trials and 6 replications in case of optimization.

\section{Colour characteristics}

Color of the peda samples was measured by reflectance spectroscopy technique employing reflectance meter, color flex (Hunter lab Miniscan XE plus Spectrocolorimeter, Virginia, USA) with geometry of diffuse $/ 8^{\circ}$ (sphere-8mm view) and an illuminant of $\mathrm{D} 65 / 10^{\circ}$. Before the test, the instrument was calibrated with standard black glass and white tile as specified by the manufacturer. The light source was dual beam xenon flash lamp. Data were received from the software in terms of $L^{*}$ [Lightness, ranges 0 (black) to 100 (White)], a* [Redness, ranges from +60 (red) to -60 (green)], and $b^{*}$ [Yellowness, ranges from +60 (yellow) to -60 (blue)] in values of the international color system.

\section{RESULTS AND DISCUSSIONS}

The amount of powder extract obtained from the adopted procedure was $20 \mathrm{~g}$, including handling losses. Therefore, the yield of powder was 10 percent. The antioxidant activity in standardized product was detected to be 31.54 per cent. Fat, protein, moisture, total solids and ash content of the standardized product as recorded on day '0' were 19.78 per-cent, 17.6 per-cent, 13.8 per-cent, 86.2 per-cent and 3.39 per-cent respectively.
Table I. Sensory scores recorded for the different colour concentrations.

\begin{tabular}{|c|c|c|c|c|}
\hline $\begin{array}{l}\text { Attribute } \\
\text { Treatment }\end{array}$ & Flavour & $\begin{array}{l}\text { Body and } \\
\text { texture }\end{array}$ & $\begin{array}{l}\text { Colour and } \\
\text { appearance }\end{array}$ & $\begin{array}{l}\text { Overall } \\
\text { acceptability }\end{array}$ \\
\hline 1 & $\begin{array}{l}7.67 \pm \\
0.14^{\mathrm{a}}\end{array}$ & $\begin{array}{l}6.89 \pm \\
0.196^{a}\end{array}$ & $\begin{array}{ll}7.11 & \pm \\
0.179 \mathrm{a} & \end{array}$ & $\begin{array}{ll}7.139 & \pm \\
0.179 \mathrm{a} & \end{array}$ \\
\hline 2 & $\begin{array}{l}7.61 \pm \\
0.164^{\mathrm{ab}}\end{array}$ & $\begin{array}{ll}7.5 \quad \pm \\
0.185^{b}\end{array}$ & $\begin{array}{ll}7.22 & \pm \\
0.236^{a} & \end{array}$ & $\begin{array}{ll}7.389 & \pm \\
0.2574^{\mathrm{a}} & \end{array}$ \\
\hline 3 & $\begin{array}{l}6.94 \pm \\
0.274^{\mathrm{bc}}\end{array}$ & $\begin{array}{l}6.44 \pm \\
0.258^{a}\end{array}$ & $\begin{array}{ll}6.22 & \pm \\
0.286^{b} & \end{array}$ & $\begin{array}{ll}6.556 & \pm \\
0.2585^{b} & \end{array}$ \\
\hline 4 & $\begin{array}{l}6.72 \pm \\
0.253^{c}\end{array}$ & $\begin{array}{ll}5.06 \quad \pm \\
0.383^{c}\end{array}$ & $\begin{array}{ll}5.72 & \pm \\
0.351^{b} & \end{array}$ & $\begin{array}{l}5.75 \\
0.371^{\mathrm{b}}\end{array}$ \\
\hline
\end{tabular}

Figures are mean \pm standard error of eighteen replications. Mean with different superscripts vary significantly within a column.

\subsection{Optimization}

Table II. Sensory scores recorded for the two treatments for optimization.

\begin{tabular}{|c|l|l|l|l|}
\hline $\begin{array}{c}\text { Attribute } \\
\text { Treatment }\end{array}$ & Flavour & $\begin{array}{l}\text { Body and } \\
\text { texture }\end{array}$ & $\begin{array}{l}\text { Colour and } \\
\text { appearance }\end{array}$ & $\begin{array}{l}\text { Overall } \\
\text { acceptability }\end{array}$ \\
\hline P1 & $\begin{array}{l}7.67 \pm \\
0.211^{\mathrm{b}}\end{array}$ & $\begin{array}{l}7.33 \pm \\
0.2118^{\mathrm{b}}\end{array}$ & $\begin{array}{l}7.33 \\
0.211^{\mathrm{b}}\end{array}$ & $\mathbf{7 . 5 \pm 0 . 2 2 4 ^ { \mathrm { b } }}$ \\
\hline $\mathrm{P} 2$ & $\begin{array}{l}8.83 \pm \\
0.167^{\mathrm{a}}\end{array}$ & $\begin{array}{l}.83 \pm \\
0.167^{\mathrm{a}}\end{array}$ & $9 \mathrm{a}$ & $9 \mathrm{a}$ \\
\hline
\end{tabular}

Figures are mean \pm standard error of six replications.Mean with different superscripts vary significantly within a column.

\subsection{Evaluation of the standardized product:}

Table III.Colour properties of the standardized product as measured by reflectance spectroscopy technique.

\begin{tabular}{|c|c|}
\hline $\begin{array}{c}\text { Colour } \\
\text { parameter }\end{array}$ & Value \\
\hline $\mathrm{L}^{*}$ & $37.83 \pm 0.21$ \\
\hline $\mathrm{a}^{*}$ & $16.93 \pm 0.11$ \\
\hline $\mathrm{b}^{*}$ & $32.93 \pm 0.18$ \\
\hline
\end{tabular}

Figures are mean \pm standard error of six replications.

\subsection{Preliminary standardization}


Table IV.Physico-chemical attributes of the standardized product

\begin{tabular}{|c|c|}
\hline Attribute & Value \\
\hline Moisture & $13.78 \pm 0.04$ \\
\hline $\begin{array}{c}\text { Titratable } \\
\text { acidity }\end{array}$ & $0.23 \pm 0.004$ \\
\hline $\mathrm{pH}$ & $6.45 \pm 0.01$ \\
\hline FFA & $9.72 \pm 0.23$ \\
\hline TBA & $0.17 \pm 0.001$ \\
\hline Tyrosine & $7.1 \pm 0.18$ \\
\hline
\end{tabular}

Figures are mean \pm standard error of six replications.

\section{CONCLUSION:}

The current study revealed that the use of Caesalpiniasappan Linn for colouring of peda yielded a highly palatable and appealing product which possessed good anti-oxidant activity. Moreover the standardized product possessed a better chemical quality as compared to the traditional lal/brown peda.

\section{REFERENCES}

[1] Aneja R. P., Mathur B. N., Chamdan R C, Banerjee A K. 2002. Technology of Indian milk products. A Dairy India Publication, New Delhi.

[2] AOAC [Association of Official Analytical Chemist]. 1997. The Official Methods of Analysis of AOAC International Association of Official Analytical Chemists. (17th Ed.). Association of Official Analytical Chemist, Washington D.C.

[3] Lioe, H. N., Adawiyah, D. R. and Anggraeni, R. 2012. Isolation and characterization of the major natural dyestuff component of Brazilwood (Caesalpiniasappan L.). Int. Food Res. J. 19: 537-542.

[4] O' Keeffee, B.R., Fox, F.P. and Daly, C. 1976.Contribution of rennet and starter proteases to proteolysis in cheddar cheese. J. Dairy Res .43: 97-102.

[5] Sachdeva, S. 1983. Production, Packaging and Preservation of paneer. Ph.D.thesis, Kurukshetra University, Kurukshetra, 130p.

[6] SP: 18 (part XI), 1981. Handbookof food analysis XI, Published by- Bureau of Indian standards, New Delhi. Pp 165 